\title{
ADAPTATION STRATEGY FOR THE MUNICIPALITY OF LA PAZ, MEXICO: MULTICRITERIA AND COST-BENEFIT ANALYSIS
}

\author{
A. IVANOVA, E. RAMÍREZ \& A. MARTINEZ \\ Universidad Autónoma de Baja California Sur, Mexico.
}

\begin{abstract}
This paper identifies climate change adaptation measures in the municipality of La Paz, Mexico, based on the results of previous vulnerability analysis. To prioritize the specified measures the GIZ methodology is used base don milticriteria and cost-benefit analysis. The study comprises the following stages, firstly policies and instruments suggested by the academic team, were discussed and slightly modified at a meeting with the representatives of La Paz Municipality. Secondly, a survey was applied to the main directors and employees according to the criteria provided by the GIZ methodology. Thirdly, a Public Consultation Forum was organized with the main stakeholders of La Paz municipality (NGO, Business, professional associations), where the adaptation measures were ranked by thematic and multicriteria approach. This stage complemented the multicriteria analysis and presented the measures that ranked in first places. The last step consisted in the cost- benefit analysis that provided a further ranking to the measures and specified the short-term adaptation strategy for the city of La Paz. The main areas of this strategy are the following: I. Hydric resources; II. Coasts and Tourism; III. Fisheries and biodiversity; IV: Urban Planning and Infrastructure; V. Environmental education and research. Finally, we present the adaptation strategy for La Paz municipality based on the prioritized adaptation measures. Keywords: adaptation strategy, cost-benefit analysis, mexico, multicriteria analysis, municipality of La Paz
\end{abstract}

\section{INTRODUCTION: CONTEXT OF THE STUDY}

The municipality of La Paz is located in the southern region of the peninsula of Baja California on the east coast of the Gulf of California and has a maximum altitude of 27 meters above sea level. According to the 2014 National Census of Population and Housing of Mexico, it has 251871 inhabitants and is experiencing an accelerated population growth [1]. The region is characterized by desert and arid ecosystems. Rain is rare and reaches an average of only 180 $\mathrm{mm}$ per year. Most of the rainfall comes from hurricanes whose violence has caused, at least every two years, historical disasters in this region [2].

The municipality of La Paz is located in one of the Mexican states with the greatest wealth and development potential. Baja California Sur is Mexico's largest coastal state $(22 \%$ of Mexico's coastline), which is distributed between the Pacific Ocean and the Gulf of California and is located in the southern half of the Baja California Peninsula. That gives it an almost insular situation. It is a geographical region privileged by its natural resources and wealth of heritage. The state of Baja California Sur has natural, historical, cultural and economic value that constitutes great tourist attraction of national and international relevance [3]. The high natural value of the region is reflected and promoted by the establishment of a large number of Protected Natural Areas (PNA). More than $40 \%$ of its territory is part of some ANP modality [4], including areas cataloged by UNESCO in the category Of World Heritage and seven Ramsar sites.

The development of the municipality of $\mathrm{La} \mathrm{Paz}$ is based on national and international tourism. However, over the last two decades, the consolidation of tourism as the main source of resources has led to a number of problems concerning natural resources for the construction of modern resorts and uncontrolled growth in vulnerable areas. Due to its desert character and 
low precipitation, the municipality has historically suffered from water supply problems. Overexploitation of aquifers has challenged the municipality's tourism vocation and the sustainability of its current development model, which is forcing the authorities to rethink their future based on the availability of water resources [5]. Likewise, this overexploitation together with sea level rise has brought problems of saline intrusion, further worsening its fragile relationship with water. Likewise, due to its coastal condition and the low altitude of its urban displacements there is a concern about the effects of climate change and possible hydrometeorological disturbances [6] that may affect the region, mainly in relation to floods caused by the intensity of hurricanes and storms [7], sea level rise [8] and availability of water. These effects are expected to affect not only the socio-economically most vulnerable groups [9], but also fisheries and agriculture as well as municipal infrastructure.

The outlook for future economic growth for the municipality of La Paz seems to be good. However, the growth trigger is likely to come from very few sectors and cause adverse effects on the sustainability of the economy. Industry and agriculture will continue to contribute to the economy, but they do not appear to show a tendency to grow significantly in the coming years. These sectors will not be able to solve the competitive disadvantages that arise from low population density, geographic isolation and high vulnerability to climate change in Baja California Sur [10, 11]. Trade and services will maintain their position as the main promoters of the economy, but the performance of these sectors depends on global economy, and does not constitute a significant source of independent growth. Under the trend of current growth, the municipality of La Paz will grow rapidly in the coming decades based on external sources. In particular, tourism and real estate companies will play a catalytic role for future growth [2]. It is therefore very important to structure adaptation measures at the municipality level $[12,13]$.

As the population and economy of the municipality of La Paz grow in the following decades, decision makers will face many challenges, such as drinking water supply, adaptation to the effects of climate change, social justice, and fiscal sustainability, protection of fragile marine and terrestrial ecosystems in the region. At the same time, the municipality has the challenge to reduce poverty and immigration, while maintaining the economic health of the city's historic core, promoting tourism and properly managing development for the benefit of the residents.

There is a State Action Program on Climate Change for Baja California Sur [3]. However, the recognition of regional particularities obliges to establish programs with municipal resolution. On the other hand, the Action Plan for Climate Change already exists for the City of La Paz (state capital) and its surrounding areas [2]. The recently provided Assessment of Current and Future Vulnerability to Climate Change of the Municipality of La Paz, BCS [14] shows and analyses the main vulnerabilities to climate change in the area and serves as a basis for the elaboration of the adaptation strategy.

Given the above, we seek to develop an Adaptation Strategy for Climate Change for the municipality of La Paz, which recognizes the extreme vulnerability of this area derived from its geographical location and specific conditions.

\section{METHODOLOGY}

\subsection{Multicriteria analysis}

This section presents the prioritization processes according to the multicriteria analysis of the adaptation measures of the Strategic Adaptive Axes (SAA). First, we presents the results of 
the meeting-workshop with public servants of the Municipality de La Paz, which took place on February 9, 2017; followed by the prioritization criteria used in the surveys applied to public servants in February 2017. Subsequently, we explain the methodology implemented at the Citizen Consultation Forum (CCF), held on February 24, 2017.

The multicriteria analysis is a support tool in the decision-making process and is part of the methodology developed by the German Cooperation for Sustainable Development (GIZ) in

Table 1: Criteria applied in the survey of municipal directors and employees.

C1. There is no transversality (0)

Transversality It is transversal with 1 or 2 policies, programs and/or projects (1-5)

It is transversal with more than 2 policies (6-10)

C3. Feasibility The measure does not consider the necessary capacities for its development (0)

The measure considers at medium level the necessary capacities for its development (1-5)

The measure considers extensively the necessary capacities for its development (6-10)

C5. Level of conservation and contribution to the resilience, not favorable (0)

Conservation of Medium level of conservation and contribution to the resilience (1-5)

Ecosystems High level of conservation and contribution to the resilience (6-10)

C7. Attention The measure does not address or worsens the conditions of vulnerability ( 0 )

to Social The measure is moderately focused on the care of the most vulnerable

Vulnerable population (1-5)

Population The measure is highly focused on the care of the most vulnerable population (6-10)

C8. Active Neither the beneficiaries nor the target population are involved in any

Participation phase of the process (0)

Only the beneficiaries or only the target population are involved at some stage of the project (1-3)

The beneficiaries or the target population are involved in some phase of the project phases (4-6)

Both the beneficiaries and the target population appropriate the measure in most of the project phases (7-10)

C9. Capacity- The measure lacks capacity building (0)

building for The measure promotes moderately the capacities (1-5)

adaptation The measure promotes strongly the capacities (6-10)

C10. Evaluation There is no monitoring mechanism (0)

and Feedback There is no monitoring mechanism, but this can be developed (1-5)

There is monitoring mechanism (6-10)

Source: Adapted from Refs. [17, 18]. 
conjunction with SEMARNAT to prioritize adaptation measures to climate change [16]. It is used to facilitate the way to the decision, so that different points of view may intervene, even if they may be contradictory. It is a support tool in the decision-making process, especially in planning, because it allows integrating different criteria in a single framework of analysis, according to the intervention of the participants.

As a first step, a survey was applied to the main directors and employees according to the criteria provided by the GIZ methodology. Table 1 shows the criteria of this survey.

As a second step of multicriteria methodology, a Citizen Consultation Forum (CCF) was carried out with the objective to gather the observations and comments of the inhabitants of the municipality of La Paz. These served to enrich and further specify the strategies and lines of action of each Strategic Adaptation Axis, both by the society, and by the agencies that would be responsible for their implementation and follow-up [17]. In addition, as part of the CCF activities, the participants prioritized the actions of each Strategic Axis based on the multicriteria analysis.

A number of representatives of civil society [18] from the municipality of La Paz participated, including offices of the three levels of government, nongovernmental organizations, producer associations and representatives of educational institutions.

Forum attendees were organized into five working tables, each with facilitator (member of the research team) and a rapporteur. Each table corresponded to the adaptation measures of a strategic sector. The Strategic Axes defined in previous meetings with public officials of the City of La Paz were Water and Desertification; Coasts and Tourism; Fisheries and Biodiversity; Urban Planning and Infrastructure; and Environmental Education and Research. Starting the work of each thematic group, the facilitator presented the work dynamics. After explaining the dynamic issue clearly, participants were asked to write individually each idea or piece of information on a tab. The participants placed their sheets in screens, where the facilitator synthesized the information (eliminating repetitions).

One of the most common techniques used was to encourage discussion and organize ideas into files. The tokens were used in the 'brainstorming' and in working with the discussion groups. The discussion took place in two stages:

\subsection{Impact and adaptation measures}

At this stage the impacts of climate change were identified by the assistants, for example, drought, flooding, sea level rise, etc. Then the level of affectation of each impact was ranked between 0 and 3 ( 0 - no affectation; 1 - affects little; 2 - affects considerable; 3 - affects a lot). Then the consequences of the impact were defined (for example, drought affects crops, sea level rise affects the coastal infrastructure, etc.).

Then the FCC participants defined the most appropriate adaptation strategies according to each impact. Once the adaptation strategies formulated, it was discussed if any support is received for their implementation by governmental institutions or by NGOs (e.g. financing, capacity building and environmental education).

Prioritization of adaptation measures identified in the previous stage

The prioritization was performed according to the multicriteria methodology. The FCC participants discussed the following six criteria, ranking each of them from 0 to 3 : 
i. Importance for the community.

ii. Contribution to conservation.

iii. Care for vulnerable population.

iv. Resilience enforcement.

v. Community participation.

vi. Institutional support (government and/or NGOs).

Then each group of answers was discussed. Subsequently, the ideas were agreed, and possible solutions to the problem were identified.

C. Cost - benefit analysis

In the third stage of adaptation measures ranking, those prioritized by multicriteria analysis were evaluated according to the cost-benefit method $[17,18]$.

The cost-benefit analysis was performed in short-term perspective, according to the request of public servants of the municipality of La Paz. Some of these measures were difficult to quantify, so we explained these benefits in qualitative way. On the other hand, for some measures there are no data at all (or updated data) to quantify most of the measures. Valuation data were largely obtained from previous publications or interviews with experts.

The cost-benefit analysis is a financial tool that measures the relationship between the costs and benefits associated with a project or adaptation measure in order to evaluate its profitability. In the case of adaptation measures, we took into account also the externalities, which are additional benefits generated by the implementation of the measure in a social or environmental context. In the next section, we deliver the result of the prioritization of measures according to the multicriteria and cost-benefit analysis.

\section{RESULTS: ADAPATATION MEASURES RANKED BY MULTICRITERIA AND COST-BENEFIT ANALYSIS BY STRATEGIC ADAPTATION AXES}

This section determines the measures that will generate the adaptation strategy for the municipality of La Paz, by complementing the results obtained from the multicriteria analysis to the results of cost-benefit analysis. These results are very important for decision-making by municipality directors and employees $[19,20]$. The following tables present the results by strategic axis.

Table 2. Combined prioritization of adaptation measures (multicriteria analysis and costbenefit analysis) for SAA I 'Water and Desertification'

\begin{tabular}{|c|c|c|}
\hline $\begin{array}{l}\text { SAA I. WATER AND } \\
\text { DESERTIFICATION }\end{array}$ & $\begin{array}{l}\text { AVERAGE RANK } \\
\text { BASED ON MULTIC- } \\
\text { RITERIA ANALYSIS }\end{array}$ & $\begin{array}{l}\text { NET BENEFIT } \\
\text { BASED ON COST- } \\
\text { BENEFIT ANALYSIS }\end{array}$ \\
\hline Increase the use of treated water & 8 & $\$ 356,962,000.00$ \\
\hline $\begin{array}{l}\text { Study water quality and pollution of } \\
\text { groundwater and soil (indicators) }\end{array}$ & 7 & $\$ 165,230,000.00$ \\
\hline $\begin{array}{l}\text { Modernize the water network and } \\
\text { reduce leaks }\end{array}$ & 7 & $\$ 31,850,517$ \\
\hline
\end{tabular}

Source: Prepared by the authors and based on multicriteria and cost-benefit analysis performed. 
Table 3: Combined prioritization of adaptation measures (multicriteria analysis and costbenefit analysis) for SAA II 'Coasts and Tourism'.

\begin{tabular}{|c|c|c|}
\hline SAA II. COASTS AND TOURISM & $\begin{array}{l}\text { AVERAGE RANK } \\
\text { BASED ON MULTIC- } \\
\text { RITERIA ANALYSIS }\end{array}$ & $\begin{array}{l}\text { NET BENEFIT } \\
\text { BASED ON COST- } \\
\text { BENEFIT ANALYSIS }\end{array}$ \\
\hline $\begin{array}{l}\text { Establish construction guidelines for the } \\
\text { coasts and link with the Mexican National } \\
\text { Waters Law, and BCS Water Law }\end{array}$ & 7.8 & $\$ 9,826,100.00$ \\
\hline $\begin{array}{l}\text { Implement solid and liquid waste manage- } \\
\text { ment programs on the coast }\end{array}$ & 8 & N/A \\
\hline
\end{tabular}

Source: Prepared by the authors and based on multicriteria and cost-benefit analysis performed.

Table 4: Combined prioritization of adaptation measures (multicriteria analysis and costbenefit analysis) for SAA III 'Fisheries and Biodiversity'.

\begin{tabular}{|c|c|c|}
\hline $\begin{array}{l}\text { SAA III. FISHERIES AND } \\
\text { BIODIVERSITY }\end{array}$ & $\begin{array}{l}\text { AVERAGE RANK } \\
\text { BASED ON MULTICRI- } \\
\text { TERIA ANALYSIS }\end{array}$ & $\begin{array}{l}\text { NET BENEFIT } \\
\text { BASED ON COST- } \\
\text { BENEFIT ANALYSIS }\end{array}$ \\
\hline $\begin{array}{l}\text { Create hunting ranches for deer 'bura' } \\
\text { and lamb 'cimarron' }\end{array}$ & 7 & $\$ 159,022,688.00$ \\
\hline $\begin{array}{l}\text { Promote responsible aquaculture } \\
\text { practices }\end{array}$ & 7 & $\$ 21,583,000.00$ \\
\hline Exploit new species of fish & 7.8 & N/A \\
\hline
\end{tabular}

Source: Prepared by the authors and based on multicriteria and cost-benefit analysis performed.

Table 5: Combined prioritization of adaptation measures (multicriteria analysis and costbenefit analysis) for SAA V 'Urban Planning and Infrastructure'.

\begin{tabular}{|c|c|c|}
\hline $\begin{array}{l}\text { SAA IV. URBAN PLANNING AND } \\
\text { INFRASTRUCTURE }\end{array}$ & $\begin{array}{l}\text { AVERAGE RANK } \\
\text { BASED ON MULTICRI- } \\
\text { TERIA ANALYSIS }\end{array}$ & $\begin{array}{l}\text { NET BENEFIT BASED } \\
\text { ON COST-BENEFIT } \\
\text { ANALYSIS }\end{array}$ \\
\hline $\begin{array}{l}\text { Prevent the growth of the cities of La } \\
\text { Paz, Todos Santos and Los Barriles to } \\
\text { areas of high vulnerability and to areas } \\
\text { of water recharge }\end{array}$ & 8 & $\begin{array}{l}\text { MXN \$ } \\
7,363,000,000.00\end{array}$ \\
\hline $\begin{array}{l}\text { Reforestation in areas of water re- } \\
\text { charge and development of more green } \\
\text { areas. Use of local plants with low } \\
\text { water consumption. }\end{array}$ & 7.6 & N/A \\
\hline $\begin{array}{l}\text { Conduct feasibility analysis of large } \\
\text { projects and works }\end{array}$ & 8 & MXN \$ 17,514.57 \\
\hline
\end{tabular}

Source: Prepared by the authors and based on multicriteria and cost-benefit analysis performed. 
Table 6: Combined prioritization of adaptation measures (multicriteria analysis and costbenefit analysis) for SAA V 'Environmental Education and Research'.

\begin{tabular}{lll}
\hline $\begin{array}{l}\text { SAA V. ENVIRONMENTAL } \\
\text { EDUCATION AND RESEARCH }\end{array}$ & $\begin{array}{l}\text { AVERAGE RANK } \\
\text { BASED ON MULTICRI- } \\
\text { TERIA ANALYSIS }\end{array}$ & $\begin{array}{l}\text { NET BENEFIT } \\
\text { BASED ON COST- } \\
\text { BENEFIT ANALYSIS }\end{array}$ \\
\hline $\begin{array}{l}\text { Communication (social networks, } \\
\text { brochures, and others) }\end{array}$ & 9 & $\$ 214,000.00$ \\
$\begin{array}{l}\text { Research (priority projects such as } \\
\text { water recharge areas, alternative crops, } \\
\text { species for aquaculture, etc.) }\end{array}$ & 9 & $\$ 2,400,000.00$ \\
$\begin{array}{l}\text { Dissemination of environmental } \\
\text { education programs and information } \\
\text { through art and culture }\end{array}$ & 7 & $\$ 480,000.00$ \\
\hline
\end{tabular}

Source: Prepared by the authors and based on multicriteria and cost-benefit analysis performed.

\section{CONCLUSIONS}

This paper defines and analyzes the adaptive strategy that addresses the important consequences of climate change in society and economy of the municipality of La Paz. Important impacts are already seen and expected in the future, in productive sectors such as tourism, fisheries, agriculture and livestock, as well as in fundamental development factors such as water availability, public health, risks associated with extreme events, based on vulnerability in short, medium and long term. The next step to specify the adaptation strategy for the municipality of La Paz would be to define the monitoring mechanisms for each of the determined measures.

The Adaptation Strategy to Climate Change of the municipality of La Paz allows continuing the process of strengthening the analysis, design and implementation of policies related to climate change, and supports the development of capacities at the regional and local level. This benefits the population in environmental, social and economic aspects. The results contribute to the efforts to develop programs such as the Emerging and Developing Cities of IDB, the Municipal Development Plan 2015-2019 of La Paz, the State Program of Climate Change Action of Baja California Sur, the Mexico's Special Climate Change Program 2014 2018. It is important to comply with the commitments made by the country to the United Nations Framework Convention on Climate Change (UNFCCC) and the Paris Agreement.

The analysis and the results presented here, can be used by local authorities to generate proposals for public policies, tending to reduce (or at least attenuate) the impacts of climate change in the highly vulnerable municipality of La Paz. The relevance is high recognizing that its economic development and social wellbeing is based on three sectors (fisheries, agriculture and tourism) highly dependent on natural resources and Eco services. To implement the Adaptation Strategy authentic governance must be created where all local stakeholders have to be active part in the planning, implementation and monitoring of each measure. 


\section{REFERENCES}

[1] INEGI. Anuario Estadístico y Geográfico por Entidad Federativa 2014. México: Instituto Nacional de Estadística y Geografía, 2014.

[2] Ivanova, A. \& Bermúdez, A., Plan de Acción ante el Cambio Climático para La Paz y sus Zonas Colindantes, PACC-LAP, 2013. Available at: http://www.lapaz.gob.mx/ images/stories/cambioclima.zip

[3] Ivanova, A. \& Gámez, A., Plan Estatal de Acción ante el Cambio Climático, PEACC 2012. Available at: http://spyde.bcs.gob.mx/cgds/files/proyectos/PEACC/foros/ Presentacion_Informativa_Foros_PEACC.pdf. (Accessed 05 March 2016).

[4] Carabias, J., Arriaga, V. \& Cervantes Gutiérrez, V., Las políticas públicas de la restauración ambiental en México: limitantes, avances, rezagos y retos. Boletín de la Sociedad Botánica de México, México, pp. 85-100, 2007.

[5] Ivanova, A., El cambio climático y el turismo: impactos, adaptación y mitigación. En: Ivanova, A. e Ibáñez, R. (coords.), Medio Ambiente y política turística en México, Tomo I: Ecología, biodiversidad y desarrollo turístico. México: Secretaría de Medio Ambiente y Recursos Naturales, pp. 67-88, 2012.

[6] IPCC. Summary for Policymakers. In: Climate Change 2013: The Physical Science Basis. Contribution of Working Group I to the Fifth Assessment Report of the Intergovernmental Panel on Climate Change [Stocker, T.F., D. Qin, G.-K. Plattner, M. Tignor, S. K. Allen, J. Boschung, A. Nauels, Y. Xia, V. Bex \& P.M. Midgley (eds.)]. Cambridge University Press, Cambridge, United Kingdom, 2013.

[7] IPCC. Managing the Risks of Extreme Events and Disasters to Advance Climate Change Adaptation. A Special Report of Working Groups I and II of the Intergovernmental Panel on Climate Change [Field, C.B., V. Barros, T.F. Stocker, D. Qin, D.J. Dokken, K.L. Ebi, M.D. Mastrandrea, K.J. Mach, G.-K. Plattner, S.K. Allen, M. Tignor, and P.M. Midgley (eds.)]. Cambridge University Press, Cambridge, UK, and New York, NY, USA, 2012.

[8] IPCC. (2014). Cambio climático 2014: Impactos, adaptación y vulnerabilidad Resumen para responsables de políticas. Contribución del Grupo de trabajo II al Quinto Informe de Evaluación del Grupo Intergubernamental de Expertos sobre el Cambio Climático [C.B. Field, V.R. Barros, D.J. Dokken, K.J. Mach, M.D. Mastrandrea, T.E. Bilir, M. Chatterjee, K.L. Ebi, Y.O. Estrada, R.C. Genova, B. Girma, E.S. Kissel, A.N. Levy, S. MacCracken, P.R. Mastrandrea \& L.L. White (eds.)]. Organización Meteorológica Mundial, Ginebra, Suiza, 2014,

[9] Moreno, A.R. \& Urbina Soria, J., Impactos sociales del cambio climático en México. México: Instituto Nacional de Ecología-Programa de las Naciones Unidas para el Desarrollo, 2008.

[10] SEMARNAT., Estrategia Nacional de Cambio Climático. Visión 10-20-40. México: Secretaría de Medio Ambiente y Recursos Naturales, 2013.

[11] SEMARNAT. Adaptación al cambio climático en México: visión, elementos y criterios para la toma de decisiones. México: Instituto Nacional de Ecología y Cambio Climático, Secretaría de Medio Ambiente y Recursos Naturales, 2012.

[12] SEMARNAT. Programa Especial de Cambio Climático 2014-2018. México: Secretaría de Medio Ambiente y Recursos Naturales, 2014.

[13] SEDESOL. Guía Municipal de Acciones frente al Cambio Climático. México: Secretaría de Desarrollo Social, 2012. 
[14] Ivanova, A., Reyes, H., Wurl, J., Serrano, R., Salvadeo, C., Ramírez, E., Hernández, P., Gómez, G. \& Petatan, D., Proyecto para la elaboración del componente de evaluación de Vulnerabilidad actual y futura ante el Cambio Climático del Municipio de La Paz, B.C.S., Informe Técnico, GIZ, Ayuntamiento de La Paz, 2016.

[15] GIZ \& SEMARNAT., Metodología para la identificación y priorización de medidas de adaptación. México: Componente de Adaptación de la Alianza Mexicana-Alemana de Cambio Climático de la Cooperación Alemana al Desarrollo Sustentable (GIZ), 2013.

[16] Zorrilla, M. \& Kuhlmann, A., Metodología de Priorización Medidas de Adaptación al Cambio Climático. Guía de uso y difusión. México: Secretaría de Medio Ambiente y Recursos Naturales (SEMARNAT) -Deutsche Gesellschaft für Internationale Zusammenarbeit (GIZ), 2015.

[17] SEMARNAT., Taller multi-actores para el diseño de políticas públicas de adaptación. México: Secretaría de Medio Ambiente y Recursos Naturales, 2011.

[18] Magaña, R.V., Guía Metodológica para la Evaluación de la Vulnerabilidad ante el cambio Climático. México: Instituto Nacional de Ecología y Cambio ClimáticoPrograma de las Naciones Unidas para el Desarrollo, 2012.

[19] UNEP. Climate: A Practical Framework for Planning Pro-Development Climate Policy. España: United Nations Environment Programme, 2011.

[20] PNUD. Practitioner's Guide: Capacity Development for Environmental Sustainability. Environment and Energy and Capacity Development. United Nations Development Programme, New York, 2011.

[21] Aldunce, P. \& Neri, C., Hacia la Evaluación de Prácticas de Adaptación ante la Variabilidad y el Cambio Climático. Belém: Universidad de Chile, Facultad de Ciencias Agronómicas, 2008.

[22] IIED. Indicadores para el monitoreo de la adaptación, 2014. Available at: http://pubs. iied.org/pdfs/17273SIIED.pdf 